\title{
Lower nitrogen excretion in pig husbandry by feeding: current and future possibilities
}

\author{
N. P. LENIS \\ Institute for Livestock Feeding and Nutrition Research (IVVO) P.O. Box 160, 8200 AD \\ Lelystad, Netherlands
}

Received 5 October 1987; accepted 4 December 1988

\begin{abstract}
Nitrogen retention in pigs does not usually exceed $30 \%$ of $\mathrm{N}$ intake. In countries with very high production of animal manure per hectare land, pollution of the environment with manure nitrogen is a major argument for improving $\mathrm{N}$ utilization and limiting $\mathrm{N}$ excretion by animals. Therefore the supply of amino acids in the diet should be in better agreement with the amino acid requirements of the animals. In practical pig nutrition there are some possibilities for improvement: (1) Prevent feeding excessive amounts of protein, e.g. feeding pigs better according to their requirements depending on age and physiological state; (2) Better balancing of dietary protein, including improving availability and quality of the protein. The first way offers the best possibility for reducing $\mathrm{N}$ excretion in the short run; this applies to growing pigs, with savings up to $6 \%$, and especially to breeding sows, resulting in savings up to $24 \%$. However, a real contribution to the solution of the problem of excess of $\mathrm{N}$ excretion in fattening pigs can only be achieved by better balancing of dietary protein. In practice, this means lowering the protein levels and supplementing diets with synthetic amino acids. Lowering the protein level in the diets for growing pigs by 2 percentage units results in about $25 \%$ reduction of $\mathrm{N}$ excretion.
\end{abstract}

Keywords: nitrogen pollution, nitrogen excretion, growing pigs, breeding sows, lower dietary protein levels, amino acid requirements, synthetic amino acids

\section{Introduction}

In the Netherlands, Denmark, Belgium and some parts of France, pollution of the environment with phosphorus and nitrogen originating from animal manure is becoming a major problem. This is especially the case in areas with dense populations of pigs and poultry. This leads to accumulation of phosphorus in the soil, resulting in undesirable eutrophication of the surface water. However, pollution with nitrogen is regarded as a bigger problem than phosphorus as it results in leaching of $\mathrm{NO}_{3}^{-}$nitrogen from animal manure to the surface, ground and drinking water. Recent monitoring research of the National Institute of Public Health and Environmental Protection (RIVM) at Bilthoven has shown that in the Netherlands the average 
$\mathrm{NO}_{3}{ }^{-} \mathrm{N}$ content in about 1500 groundwater samples under pasture land in sandysoil areas (depth $<6 \mathrm{~m}$ below surface) was already $25 \mathrm{mg}^{-1}$ (Krajenbrink et al., 1988). Moreover, data from the National Network Groundwater Quality (van Duijvenboden et al., 1985) showed that under sandy arable land, at a depth of $10 \mathrm{~m}$ below surface, the average $\mathrm{NO}_{3}{ }^{-} \mathrm{N}$ content of the groundwater had increased up to $19 \mathrm{mg} \mathrm{l}^{-1}$. In several cases, much higher contents were found, even up to $110 \mathrm{mg}$ $\mathrm{NO}_{3}^{-}-\mathrm{N} \mathrm{l}^{-1}$. From the data about $\mathrm{NO}_{3}^{-}-\mathrm{N}$ contents at depths of 15 and $25 \mathrm{~m}$ below surface it could be concluded that nitrate pollution is gradually moving deeper in sandy soil areas. The international standard for $\mathrm{NO}_{3}{ }^{-}-\mathrm{N}$ in drinking water is $11 \mathrm{mg}$ $1^{-1}$. So nitrate pollution is a direct danger to drinking water supplies.

Nitrogen pollution also results in emission of $\mathrm{NH}_{3}$ nitrogen into the air, contributing to bad odour and to acid rain. It has been shown (Schuurkes, 1987) that in concentration areas with intensive stockbreeding in the Netherlands the emission of $\mathrm{NH}_{3}$ and atmospheric $\mathrm{NH}_{\mathrm{x}}$ deposition are closely related to each other. Atmospheric deposition of airborne ammonium compounds has been recognized to be important in the problems of acidification of the environment (van Breemen et al., 1982; Nihlgard, 1985). It has been estimated that in the Netherlands, $\mathrm{NH}_{3}$ emission contributes for about $40 \%$ to the acidifying deposition and that about $85 \%$ of the emitted $\mathrm{NH}_{3}$ originates from volatilization from animal manure on livestock farms and liquid-manured land (Anon., 1984). In the Netherlands, the emission density of ammonia is the highest for Europe (Buijsman et al., 1987). In several wooded areas in the country, with much intensive husbandry in the neighbourhood, the health status of the woods is very poor. This environmental problem can be described to the deleterious (both direct and indirect) effects of high ammonia emission densities (Schuurkes, 1987). $\mathrm{NH}_{3}$ emission also has a very undesirable effect on vegetation in nature reserves.

For these reasons, nitrogen excretion in animal husbandry should be reduced very drastically, not only in the Netherlands but also in some other European countries. The Dutch government aims at a reduction in $\mathrm{NH}_{3}$ emissions of $50 \%$ by 1995 .

\section{Legislation}

In 1987 regulations were introduced in the Netherlands to limit manure application from ruminants, pigs, poultry and turkeys (Smit \& Dijkman, 1987). The 'Soil Conservation Act' (Anon., 1986a) and its most important instrument 'Regulations for the use of animal manure' (Anon., 1987), which came into force on 1 May 1987,

Table 1. Maximum application of $\mathrm{P}_{2} \mathrm{O}_{5}$ from animal manure in $\mathrm{kg} \mathrm{ha}^{-1} \mathrm{year}^{-1}$.

\begin{tabular}{llccc}
\hline Phase & Period & Grassland & Maizeland & Arable land \\
1 & $1.5 .1987-1.11991$ & 250 & 350 & 125 \\
2 & $1.1 .1991-1.11995$ & 200 & 250 & 125 \\
3 & from 1.1 .1995 & \pm 175 & \pm 175 & 125 \\
4 & from \pm 2000 & $?$ & $?$ & $?$ \\
\hline
\end{tabular}


Table 2. Prohibitions for application of animal manure in autumn and winter in the Netherlands.

Sandy soils

Grassland

Not covered with snow

Covered with snow

Maizeland/arable land

Not cultivated after harvest Cultivated after harvest
October and November

1 January-15 February
Other soils

October and November

1 January-15 February

control a number of topics with regard to the use of animal manure. The limitations for manure application have been expressed as $\mathrm{kg} \mathrm{P}_{2} \mathrm{O}_{5}$ per hectare of grassland, arable land and land on which maize silage is grown (Table 1). Phosphorus has been chosen as the controlling criterion instead of nitrogen, because nitrogen is much more mobile than phosphate due to gaseous $\mathrm{N}$ losses and leaching of nitrate. Furthermore, from 1988 onwards it is not permitted to spread slurry during some periods in autumn and winter in order to diminish leaching of $\mathrm{NO}_{3}^{-}$and minerals and volatilization of $\mathrm{NH}_{3}$ (Table 2).

On the basis of the 'Manure Act' (Anon., 1986b) manure production has been registrated and a levy-system has been put forward. Farmers are charged for surplus $P$ from their farms. Pig and poultry farmers are charged less and are allowed to apply more manure per hectare of land if they use diets which contain less $\mathrm{P}$ than the standard diets. In the case of pigs, however, these diets should contain less $\mathrm{N}$ as well in order to prevent an increase in $\mathrm{N}$ load per hectare of land.

These and some other measures should insure that the surplus of manure/minerals and the related problems do not increase up to 1990 and will diminish subsequently. However, the latter is almost impossible without some drastic measures in animal feeding. There are several possibilities in this area, not only in pig feeding but also in ruminant and poultry feeding. Total $\mathrm{N}$ excretion of cattle in the Nether-

Table 3. Annual excretion in the Netherlands of $\mathrm{N}$ and $\mathrm{P}$ by several categories of animals (Jongbloed et al., 1985).

\begin{tabular}{lccrrr}
\hline & \multicolumn{2}{l}{ Per animal $(\mathrm{kg})$} & & \multicolumn{2}{c}{ Total per category (ton) } \\
\cline { 2 - 3 } \cline { 5 - 6 } & $\mathrm{N}$ & $\mathrm{P}$ & & $\mathrm{N}$ & $\mathrm{P}$ \\
Dairy cattle & 134.5 & 17.0 & & 336.250 & 42.625 \\
Young cattle & 50.2 & 5.8 & & 90.450 & 10.530 \\
Beef cattle & 38.3 & 6.2 & & 11.500 & 1.850 \\
Veal calves & 9.5 & 1.8 & & 5.676 & 1.092 \\
Sows & 22.4 & 6.4 & & 29.120 & 8.281 \\
Growing pigs & 12.9 & 3.3 & & 76.230 & 19.470 \\
Laying hens & 0.63 & 0.20 & & 25.882 & 8.054 \\
Broilers & 0.38 & 0.10 & & 18.816 & 5.092 \\
\hline
\end{tabular}


lands is almost four times the nitrogen excretion of the Dutch pig stock (Table 3, Jongbloed et al., 1985). However, research is concentrating on the animals in intensive husbandry, i.e. pigs and poultry, because in general, pig and poultry farms have the biggest surplus of manure per hectare of land.

\section{Feeding measures}

It is clear that, if reduction of $\mathrm{N}$ excretion of pigs is the objective than the protein/ amino acid balance in the diet must be examined. The pig needs the amino acids in the dietary protein mainly for body protein synthesis. In addition to the requirement for new tissue formation, some protein is required for maintenance. Thus an animal's requirement for protein varies according to its age and physiological state, whether it is growing or full-grown, or, concerning breeding animals, whether they are non-pregnant, pregnant or lactating.

A part of dietary protein is indigestible and this results in a quantity of $\mathrm{N}$ in the faeces. However, a much bigger proportion of the pigs' $N$ excretion appears in the urine, mainly as a result of degradation of superfluous amino acids which cannot be used for body protein deposition. Also protein digested in the hindgut is excreted almost entirely as urinary $\mathrm{N}$.

Usually pig diets are formulated by linear programming. In the Netherlands this occurs on the basis of certain requirements for digestible lysine and methionine + cystine. The amino acid composition of Dutch feedstuffs is such that if these allowances are met there will be an oversupply of other amino acids. This oversupply is responsible for the largest part of urinary $\mathrm{N}$ excretion. So the closer the balance of amino acids in the diet is to the amino acid requirements of the animals, the less protein is wasted and the less nitrogen is excreted in the urine. There are two main ways to achieve this:

1. Prevent feeding excessive amounts of protein, e.g. feeding pigs better according to their requirements depending on age and physiological state.

2. Better balancing of dietary protein, including improving availability and quality of the protein.

Feeding pigs a balance of amino acids which is in better agreement with age and physiological state offers the best possibility for reducing $\mathrm{N}$ excretion in the short run. This applies to growing pigs and especially to breeding sows. A real contribution to the solution of the problem of excess $\mathbf{N}$ excretion in fattening pigs can only be achieved by a much better balancing of dietary protein. However, the present economic conditions are such that this goal cannot be reached in the short run, but mainly in the longer run.

Feeding pigs in better agreement with age and physiological state

\section{Growing pigs}

In the Netherlands, up to now, growing pigs in the live-weight range from 45 to 106 $\mathrm{kg}$ are fed with one type of fattening feed with a crude protein content of about 
Table 4. $\mathrm{N}$ contents in pig diets $\left(\mathrm{g} \mathrm{kg}^{-1}\right), \mathrm{N}$ intake and $\mathrm{N}$ excretion $\left(\mathrm{kg} \mathrm{pig}^{-1}\right)$ over the live weight range $25-106 \mathrm{~kg}$ in the traditional and in the new system.

\begin{tabular}{lllll}
\hline System & & N content & N intake & N excretion \\
Traditional & starter diet & 27.2 & 6.04 & 4.18 \\
& fattening feed & 24.0 & & \\
New & starter diet & 27.2 & & \\
& grower diet & 24.0 & 5.78 & 3.92 \\
& finishing diet & 22.4 & & \\
\hline
\end{tabular}

$15 \%$ or higher. In the starter period, 25 to $45 \mathrm{~kg}$, the pigs are fed a baby-piglet diet or a starter diet. In 1985, according to Dutch TEA figures (Arkes et al., 1985), average daily gain in the range of 25 to $106 \mathrm{~kg}$ was $679 \mathrm{~g}$, average feed conversion ratio was 3.04 , and feed consumption amounted to $43 \mathrm{~kg}$ starter diet and $203 \mathrm{~kg}$ fattening feed.

Currently, partially in order to overcome adaptation problems when pigs are switched from the starter diet to the fattening feed, some producers are introducing an extra diet in the fattening period. In this system, a grower diet is fed in the range of 40 to $65 \mathrm{~kg}$, followed by a finishing diet. The grower diet might have slightly higher amino acid contents than the traditional fattening feed, but the crude protein content might be the same without extra costs. In the finishing diet, the crude protein and amino acid contents may be lower (14\% crude protein) because the amino acid requirements, expressed as $\mathrm{g} \mathrm{kg}^{-1}$ feed, are lower in heavier pigs. Feed intake figures in this system are about $35 \mathrm{~kg}$ of starter diet, $65 \mathrm{~kg}$ of grower diet and $146 \mathrm{~kg}$ of finishing diet. Using this system and putting total $\mathrm{N}$ retention in the range 25-106 $\mathrm{kg}$ on $81 \times 23.0 \mathrm{~g}=1.86 \mathrm{~kg} \mathrm{~N}$, it can be calculated (Table 4) that $\mathrm{N}$ excretion in the new system amounts to $3.92 \mathrm{~kg}$, against $4.18 \mathrm{~kg}$ in the traditional system, which means $6 \%$ less $\mathrm{N}$ excretion. Unfortunately, in practice up to now hardly any reduction in $\mathrm{N}$ excretion is achieved, because protein content in the finishing diet still is as high as in the traditional diet. The IVVO recommendations for amino acids in piglet

Table 5. IVVO recommendations for amino acids in some piglet and pig diets $\left(\mathrm{g} \mathrm{kg}^{-1}\right)$.

\begin{tabular}{lccccc}
\hline & $\begin{array}{l}\text { Baby-piglet } \\
\text { diet }\end{array}$ & $\begin{array}{l}\text { Starter } \\
\text { diet }\end{array}$ & $\begin{array}{l}\text { Fattening } \\
\text { feed }\end{array}$ & $\begin{array}{l}\text { Grower } \\
\text { diet }\end{array}$ & $\begin{array}{l}\text { Finishing } \\
\text { diet }\end{array}$ \\
Traject (kg) & weaning-40 & $22-40$ & $40-105$ & $40-70$ & $70-105$ \\
EW $^{1}$ & 1.07 & $1.03-1.05$ & 1.03 & 1.03 & 1.03 \\
Crude protein & $>170$ & $160-180$ & $(150)$ & $(150)$ & $(140)$ \\
Amino acids & & & & & \\
- dig. lysine & 10.0 & $>8.7$ & 7.2 & 8.0 & 6.5 \\
- dig. meth. + cys & 6.0 & 5.4 & 4.6 & 5.1 & 4.1 \\
- threonine & 7.3 & 6.5 & 5.6 & 6.1 & 5.0 \\
- tryptophan & 2.1 & 1.9 & 1.5 & 1.7 & 1.4 \\
\hline
\end{tabular}

$1.0 \mathrm{EW}=2100 \mathrm{kcal} \mathrm{NE}$ 
and pig diets are given in Table 5 (Lenis, 1988a; Lenis, 1988b). Net energy values of the pig diets are put on $1.03 \mathrm{EW}$. In practice, there is a tendency for higher values with also proportionally higher amino acid contents. A disadvantage of the new system is the need for storage of an additional feed.

A slightly bigger reduction in $\mathrm{N}$ excretion could be achieved by mixing a feed rich in protein and minerals with an energy-rich feed in a changing ratio during the fattening period. In this way the supply with amino acids can be brought in even better agreement with the actual requirements. This system could be applied rather easily in a computerized mechanical wet feeding system.

\section{Breeding sows}

Until recently, pregnant and lactating sows were fed the same type of diet in the Netherlands, which was actually formulated for lactation. Thus, waste of $\mathrm{N} \mathrm{oc-}$ curred during pregnancy, due to oversupply of protein. Currently, two different diets are introduced in sow feeding, one for pregnancy and one for lactation. There are several reasons for this, including lower feeding costs per sow per year because the diet for pregnancy is cheaper than the traditional diet, due to lower protein and phosphorus contents. The diet for lactation is more expensive because of a higher net energy content, but feed intake is proportionally lower. If protein prices increase, the advantage of the 2 -feed system will be greater. An additional reason for the interest in the 2-feed system is the potentially higher feed intake during lactation due to a higher net energy content of the diet for lactation; this is especially of interest for gilts. Finally, there is a substantially lower phosphorus and nitrogen excretion on the 2-feed system. By using this system, farmers are assessed lower surplus charges by the government.

As an example, in Table 6 the characteristics are given of the diets used in a longrun IVVO investigation into the 2-feed system for sows, particularly with regard to the minimum $P$ and $N /$ amino acid supply during pregnancy. It is worthwhile to note the low contents of digestible lysine $\left(4.0 \mathrm{~g} \mathrm{~kg}^{-1}\right.$ and crude protein $\left(102 \mathrm{~g} \mathrm{~kg}^{-1}\right.$ in the diet for pregnancy.

On the basis of a feed intake of $1100 \mathrm{~kg}$ per sow per year $(\mathrm{EW}=0.97)$, of which $35 \%$ is consumed during lactation, a culling rate of $45 \%$, a number of piglets born per sow per year of 20 , of which 17.5 are weaned - resulting in a total $\mathrm{N}$ retention of

Table 6. Some characteristics of the diets in the experiment (IVVO) with regard to the 2-feed system for sows $\left(\mathrm{g} \mathrm{kg}^{-1}\right)$.

\begin{tabular}{lccc}
\hline & $\begin{array}{l}\text { Control diet } \\
\text { (pregnancy + lactation) }\end{array}$ & $\begin{array}{l}\text { Diet for } \\
\text { pregnancy }\end{array}$ & $\begin{array}{l}\text { Diet for } \\
\text { lactation }\end{array}$ \\
EW & 0.97 & 0.97 & 1.03 \\
Crude protein & 141 & 102 & 143 \\
Dig. lysine & 6.0 & 4.0 & 6.7 \\
Dig. meth. + cys. & 4.0 & 2.7 & 4.3 \\
Dig. phosphorus & 3.1 & 1.8 & 3.0 \\
\hline
\end{tabular}


Table 7. $\mathrm{N}$ contents in sow diets $\left(\mathrm{g} \mathrm{kg}^{-1}\right), \mathrm{N}$ intake and $\mathrm{N}$ excretion $\left(\mathrm{Kg} \mathrm{sow}^{-1}\right.$ year $\left.{ }^{-1}\right)$ in the experiment with regard to the 2 -feed system for sows.

\begin{tabular}{lllll}
\hline & \multicolumn{1}{c}{ N content } & & N intake & N excretion \\
\cline { 2 - 3 } & pregnancy & lactation & & \\
Control & 22.6 & 22.6 & & \\
2-feed system & 16.3 & 22.9 & 19.9 & 20.9 \\
\hline
\end{tabular}

$4.0 \mathrm{~kg}$ per sow + piglets per year - the $\mathrm{N}$ excretion per sow per year can be estimated. This is $15.8 \mathrm{~kg} \mathrm{~N}$ per sow per year in the 2-feed system against $20.9 \mathrm{~kg} \mathrm{~N}$ in the traditional situation (Table 7). This means a $24 \%$ less $\mathrm{N}$ excretion. In practice, the reduction in $\mathrm{N}$ excretion is less, because the protein concentrations in the diets, particularly in the diet for pregnancy, are still higher.

The lysine requirement during lactation is still quite uncertain. Depending on assumptions for several starting-points (e.g. the requirement for maintenance, the efficiency of lysine utilization, the development of lysine deposition during pregnancy, protein mobilization during lactation, milk production and feed intake), very different allowances for digestible lysine can be calculated, especially for lactation. Currently it is assumed that at a daily milk production of $10 \mathrm{~kg}$, the daily requirement for digestible lysine of a lactating sow is about $46 \mathrm{~g}$, which is considerably higher than ARC and NRC estimates (ARC, 1981; NRC, 1979). The daily requirement for digestible lysine of a sow at the end of pregnancy (115 days) is estimated to be $12-14 \mathrm{~g}$ (11-13 $\mathrm{g}$ at 108 days).

\section{Better balancing of dietary protein}

There is a wide variety of feedstuffs available for pig diets, showing considerable variation in amino acid content. But, taking the price and the amino acid composition of the available feedstuffs into account, in most countries it is usually impossible to formulate diets in an economic way without oversupply of certain amino acids. Non-specific nitrogen amino acids are always supplied in adequate or excessive amounts when diets are formulated from natural feedstuffs which provide the required essential amino acids. Concerning this problem one should distinguish between possibilities in the short and long run. The short run offers only marginal contributions in solving the problems. In the long run, a minimum oversupply of amino acids will be achieved by lowering the protein levels in pig diets and supplementing diets with several synthetic amino acids.

\section{Possibilities in the short run}

The quality of protein in a diet is not only reflected by its amino acid composition but also by the availability of the amino acids. Thus, in formulating diets, one has to take into account that not all dietary amino acids are digested resulting in a faecal nitrogen output, which makes up only a minor part of total (urinary and faecal) ni- 
trogen output. Digestibility of various amino acids in the same feedstuff may be rather different, especially in less digestible feedstuffs. Also between feedstuffs, amino acid digestibility may vary. This is the reason why in recent years much work has been directed towards determining amino acid digestibility of feedstuffs in order to base protein evaluation for pigs on digestible amino acids (Lenis, 1983; Lenis, 1985). From 1984 on, a preliminary table containing digestibility data for lysine, methionine and cystine in several important feedstuffs for pigs, has been used by the Dutch feed compounders for practical diet formulation on a large scale. In this way, the feed industry is able to bring diet formulation more precisely into balance with the need for amino acids of the pig. Particularly in the Netherlands, where many by-products are used, this is of interest. It should be mentioned that, in this system, synthetic amino acids are considered $100 \%$ digestible. Although it was recognized (Lenis, 1983) that there were some differences between ileal digestibility and faecal digestibility of the limiting amino acids in feedstuffs for pigs, for practical reasons the Dutch table was based upon the apparent faecal amino acid digestibility. However, protein digested in the hindgut is excreted almost entirely as urinary nitrogen. So the ileal analysis method should be considered a further improvement, as compared to the faecal analysis method, for determining amino acid digestibilities (van Weerden et al., 1985; Sauer \& Ozimek, 1986). The planned chaige to a protein evaluation based upon ileal digestible amino acids may contribute to a further small reduction of nitrogen excretion.

Another possibility for better balancing dietary protein could be lowering the proportion of some by-products and other feedstuffs with a low ileal protein digestibility in the diet in favour of cereals and other feedstuffs with higher protein digestibilities. However, pig diets would become more expensive then, the effects on market prices of feedstuffs are unknown, and it would withdraw cereals from human consumption. The tendency in the Netherlands for using more concentrated pig diets runs only partially parallel to less by-products in those diets. For this reason the contribution of more concentrated feeds to savings in $\mathrm{N}$ excretion is very small although the effect on $\mathrm{P}$ excretion is slightly higher.

Calculations with linear programming showed which effects the lowering of protein levels in pig diets had on the price of the feeds, maintaining the allowances not only for digestible lysine and methionine + cystine but also for threonine and tryptophan (1986). Depending on the price setting of the feedstuffs, the feeding system and other conditions, lowering the crude protein level by 1 percentage unit increased the price of the feeds with Dfl. 0.10 to Dfl. 0.50 per $100 \mathrm{~kg}$ feed. In these feed compositions, synthetic lysine and methionine were included; synthetic threonine and tryptophan were not allowed in the diets. In this way, a reduction in $\mathrm{N}$ excretion can be achieved. However, a reduction in protein level of 2 percentage units, calculated in the same way, would increase the price with Dfl. 1.50 to Dfl. 3.50 per $100 \mathrm{~kg}$ feed. Inclusion of synthetic threonine and tryptophan at present prices would make it even more expensive.

In the short run, realistic feeding measures in order to get a better balanced dietary protein have only little effect on $\mathrm{N}$ excretion; at maximum, $10 \%$ less $\mathrm{N}$ excretion can be achieved. 


\section{Possibilities in the long run}

Improving the ileal digestibility of the protein in feedstuffs, e.g. by research in the field of processing conditions and anti-nutritional factors affecting ileal digestibilities (Cousins et al., 1981; Ozimek et al., 1985; van der Poel \& Huisman, 1988), contributes to reduced $\mathrm{N}$ excretion in monogastrics, mainly in the long run. However, the only way to get the supply with amino acids in the diet in very good agreement with the amino acid requirements of the pigs is lowering the protein levels in pig diets and supplementation with several synthetic amino acids. In this way, the efficiency of $\mathbf{N}$ utilization can be raised substantially. Calculations for growing pigs show that a reduction of 2 percentage units in crude protein content $\left(=3.2 \mathrm{~g} \mathrm{~N} \mathrm{~kg}^{-1}\right.$ feed) in the starter diet, the grower diet and the finishing diet results in about $25 \%$ reduction in $\mathrm{N}$ excretion per pig. This can be applied in sow feeding and piglet feeding as well. In piglet feeding in many cases a lower protein level has already been applied because of the favourable effects on health status.

It is expected that the crude protein level can be reduced by more than 2 percentage units by supplementing the feeds with lysine, methionine, threonine and tryptophan without any deleterious effects. In this way, a substantial reduction in $\mathbf{N}$ excretion can be achieved. In doing so it will be necessary that threonine and tryptophan become available at economically competitive prices for use as feed supplements, as lysine and methionine are currently. In addition, an even further price reduction for lysine and methionine will be required. In this respect it has to be expected that application of recombinant - DNA techniques to microbial production of threonine, tryptophan and other amino acids will result in the availability of these amino acids at competitive prices.

Anticipating the situation of lower protein concentrations in the diets and supplementation with several amino acids, research is currently needed into the requirements for several essential amino acids, because it will be very important to know these requirements in detail in the new situation. There are still questions about the adequacy of the ARC estimates for the Dutch situation for threonine, tryptophan and methionine + cystine. Some other aspects to which attention should be paid concern the minimum $\mathrm{N}$ supply and aspects of feeding synthetic amino acids, such as utilization in relation to meal frequency.

\section{References}

Agricultural Research Council (ARC), 1981. The nutrient requirements of pigs. Commonwealth Agricultural Bureaux, Slough, $307 \mathrm{pp}$.

Anonymus, 1984. Paper on acidification. Ministry of Housing, Physical Planning and Environment/Ministry of Agriculture and Fisheries, The Hague, $59 \mathrm{pp}$.

Anonymus, 1986a. Wet Bodembescherming (Soil Conservation Act). Staatsblad 1986, No 374.

Anonymus, 1986b. Meststoffenwet (Manure Act). Staatsblad 1986, No 598.

Anonymus, 1987. Besluit gebruik dierlijke meststoffen (Regulations for the use of animal manure). Staatsblad 1987, No 114.

Arkes, J. G., W. H. M. Baltussen, G. J. A. Ogink \& J. Schneider, 1985. Bedrijven met mestvarkens 1985. Report C1.3, Consulentschap in Algemene Dienst voor Varkenshouderij/Landbouw Econo- 
misch Instituut (State Consultancy for Pig Production/Agricultural Economics Research Institute (LEI)), Rosmalen, $54 \mathrm{pp}$.

Breemen, N. van, P. A. Burrough, E. J. Velthorst, H. F. van Dobben, T. de Wit, T. B. de Ridder \& H. F. Reynders, 1982. Soil acidification from atmospheric ammonium sulphate in canopy throughfall. Nature 299: 548-550.

Buijsman, E., H. F. M. Maas \& W. A. H. Asman, 1987. Anthropogenic ammonia emissions in Europe. Atmospheric Environment 21: 1009-1022.

Cousins, B. W., T. D. Tanksley Jr, D. A. Knabe \& T. Zebrowska, 1981. Nutrient digestibility and performance of pigs fed sorghums varying in tannin concentration, Journal of Animal Science 53: 15241537.

Duijvenboden, W. van, J. Taat \& L. F. J. Gast, 1985. Landelijk Meetnet Grondwaterkwaliteit: eindrapport van de inrichtingsfase. Report No 840382001, National Institute of Public Health and Environmental Protection (RIVM), Bilthoven, the Netherlands, $37 \mathrm{pp}$.

Jongbloed, A. W., A. Steg, P. C. M. Simons, W. M. M. A. Janssen, N. P. Lenis, J. A. C. Meijs, K. Vreman, 1985. Berekeningen over de mogelijke vermindering van de uitscheiding aan $\mathrm{N}, \mathrm{P}, \mathrm{Cu}, \mathrm{Zn}$ en $\mathrm{Cd}$ via de voeding door landbouwhuisdieren in Nederland. Mededelingen IVVO No 3, Lelystad/ COVP-Mededeling No 427, Beekbergen, 46 pp.

Krajenbrink, G. J. W., L. J. M. Bouwmans \& C. R. Meinardi, 1988. Hydro-chemical processes in the top layer of groundwater under pasture-land. In: Proceedings ISWA/DAKOFA/AUC specialized seminar 'Nitrogen in organic wastes applied to soils', University of Aalborg, Denmark (in press).

Lenis, N. P., 1983. Faecal amino acid digestibility in feedstuffs for pigs. In: R. Pion, M. Arnal \& D. Bonin (Eds), Proceedings 4th International Symposium on Protein Metabolism and Nutrition, Clermont-Ferrand (France), Vol. 2, p. 385-389. Institut National de la Recherche Agronomique, Paris.

Lenis, N. P., 1985. Amino acid, the most fundamental nutrient. Pigs 1, 4: 34-37.

Lenis, N. P., 1988a. Requirements for essential amino acids in growing pigs. Wissenschaftliche Zeitschrift der Wilhelm-Pieck-Universität Rostock, Naturwissenschaftliche Reihe 37: 68-69.

Lenis, N. P., 1988b. Amino acid requirements of growing pigs. Paper 7 th International Symposium on Amino Acids, Brno, Czechoslovakia, 7 pp.

National Research Council (NRC), 1979. Nutrient requirements of Domestic animals. No 2. Nutrient requirements of swine. National Academy of Sciences, Washington DC, $52 \mathrm{pp}$.

Nihlgard, B., 1985. The ammonium hypothesis: an additional explanation to the forest die-back in Europe. Ambio 14: 2-8.

Ozimek, L., W. C. Sauer \& G. Ozimek, 1985. Ileal and fecal digestibility of protein and amino acids and activities of pancreatic enzymes in pigs fed diets with different levels of soybean, protease inhibitor(s). In: A. Just, H. Jorgensen \& J. A. Fernandez (Eds). Proceedings 3rd International Seminar on Digestive Physiology in the Pig, Copenhagen, p. 146-148. National Institute of Animal Science, Copenhagen.

Sauer, W. C. \& L. Ozimek, 1986. Digestibility of amino acids in swine: Results and their practical aplications. A review. Livestock Production Science 15: 367-388.

Schuurkes, J. A. A. R., 1987. Acidification of surface waters by atmospheric deposition. Thesis, Catholic University, Nijmegen, the Netherlands, $160 \mathrm{pp}$.

Smit, M. J. \& G. F. Dijkman, 1987. Relationship between animal husbandry, manure production and environment in the Netherlands. Report Grontmij NV Land Utilization Department, De Bilt, 57 pp.

Poel, A. F. B. \& J. Huisman, 1988. Effect of steam treatment of dry Phaseolus vulgaris beans on ileal digestibility in pigs. In: Proceedings 4th International Seminar on Digestive Physiology in the Pig. Jablonna, Poland (in press).

Weerden, E. J. van, J. Huisman, P. van Leeuwen \& P. Slump, 1985. The sensitivity of the ileal digestibility method as compared to the faecal digestibility method. In: A. Just, H. Jorgensen \& J. A. Fernandez (Eds), Proceedings 3rd International Seminar on Digestive Physiology in the Pig, Copenhagen, p. 392-395. National Institute of Animal Science, Copenhagen. 